\title{
HISTOLOGICAL AND BIOCHEMICAL STUDY IN MICE EXPERIMENTALLY INFECTED WITH TOXOPLASMA GONDII AND EXPOSED TO AFLATOXIN
}

\author{
Ehsan G. Zakaria \\ Alaa G. Mohammad \\ Ghassan F. AL Aubaidy \\ Dept. of Pharmacy, Mosul Technical Institute. Iraq \\ E-mail: gorgees.ehsan@yahoo.com
}

\begin{abstract}
This study was conducted for examine the histological effects of aflatoxin and Toxoplasma gondii on some organs like liver, heart, kidney and brain in mice. Were, mice divided into six equal groups; group 1 (untreated control), group 2 were injected intraperitonealy with $T$. gondii tissue cysts, group 3 fed diets contaminated with 0.5 ppm of aflatoxin, group 4 were fed diets contaminated with $1 \mathrm{ppm}$ aflatoxin, group 5 were fed $0.5 \mathrm{ppm}$ of aflatoxin and injected with $T$. gondii cysts and group 6 were fed 1 ppm aflatoxin with injected $T$. gondii tissue cysts. The experiment maintained for 40 days.
\end{abstract}

At the end of the experiment, histological changes were increased specially at groups 5 and 6 including necrosis and lymphocytic infiltration, there are significantly increased in the level of MDA and significantly decrease of GSH level in liver tissue specially in groups (2) and (4) as compared with group (1) normal healthy control. Keywords: Mycotoxins, Aflatoxin, Toxoplasma gondii, Histological changes, Glutathione, Malondialdehyde.

Received: 9/4/2013, Accepted: 2/12/2013.

\section{INTRODUCTION}

Toxoplasmosis is a parasitic disease caused by the protozoan Toxoplasma gondii (Ryan etal, 2004). The parasite infects most general of warm-blooded animals, including humans, cattle, sheep, goat, rabbit, mice but the primary host is the feline (cat) family. Animals are infected by eating infected meat, or by ingestion of feces of a cat that has itself recently been infected, or by transmission from dam to infants. Cats are the primary source of infection to Human and Animals hosts, although contact with raw meat, Fecal contamination of hands is a significant risk factor (Torda, 2001). T. gondii infections have the ability to change the behavior of rats and mice, making them drawn to rather than fearful of the scent of cats. This effect is advantageous to the parasite, which will be able to sexually reproduce if its host is eaten by a cat (Berdoy etal, 2000) The infection is highly precise, as it does not affect a rat's other fears such as the fear of open spaces or of unfamiliar-smelling food.

T. gondii infections have also cause behavioral changes in humans, including slower reaction times and a six fold increased risk of traffic accidents among infected males. The prevalence of human infection by Toxoplasma varies greatly between countries (Berdoy etal, 2000). Factors that influence infection rates include diet (prevalence is possibly higher where there is a preference for less-cooked meat) and proximity to cats (Flegr etal, 2009) ; (Meerburg etal, 2009)

Aflatoxins (AF) are among the most common mycotoxins to which humans are exposed. They are highly substituted coumarin derivatives containing a fused dihydrofurofuran moiety. Human beings and mammals are exposed to aflatoxin through food/feed-stuffs, milk, meat and eggs. Consumption of AF in many parts of the world varies between $0 \mathrm{ng}-30,000 \mathrm{ng} / \mathrm{kg} / \mathrm{day}$. Epidemiological and experimental 
studies have shown that AF are hepatotoxic (Luyendyk, 2003), hepatocarcinogenic yang etal, 2000), mutagenic (Catterall etal, 2002) and teratogenic (Vismara, 2007).

Toxoplasmosis can cause serious pathologies including hepatitis, pneumonia, blindness, and severe neurological disorders. These types of diseases are seen particularly in people and animal with weak immune systems (Yazar etal, 2003); (Nishikawa et al, 2007). Yet, the pathogenic mechanisms in healthy people could not be explained completely. It is assumed that the malondialdehyde (MDA) arising from the lipid peroxidation is an indicator of the oxidative stress in tissue and cells. Lipid peroxidase is a derivative of feeble unsaturated fatty acid which is produced as a result of decomposition of a set of complex components (Koltas, etal, 2006). Glutathione (GSH), an endogen originated peptide which can be synthesized in the liver without need for genetic data, is made up of glutamic acid, cysteine and glycine amino acids, and is an important antioxidant. It defends the cells against oxidative damage by undergoing reaction with free radicals and peroxidase (Uchiyama etal, 1978).

\section{MATERIALS AND METHODS}

Animals and treatments: Sixty young inbreed Swiss female albino mice BALB/C weighting 20-25 g were obtained from animal house at the pharmacy department of Mosul technical institutes. All were negative for anti-toxoplasma antibodies in the latex agglutination test, animals were provided with feed and water ad libtium under laboratory conditions, These mice were randomly divided into six groups (10 mice per group) and caged separately:

1. Group 1 (untreated control).

2. Group 2 were injected with $T$. gondii tissue cysts.

3. Group 3 were fed diet contaminated with $0.5 \mathrm{ppm} \mathrm{AF}$.

4. Group 4 were fed diet contaminated with $1 \mathrm{ppm}$ AF.

5. Group 5 were fed diets contaminated with $0.5 \mathrm{ppm}$ AF and injected with $T$. gondii tissue cysts.

6. Group 6 were fed diets contaminated with $1 \mathrm{ppm}$ AF and injected with T. gondii tissue cysts. The experiment extended for 40 days.

Infection and autopsy: Mice were intraperitonealy inoculated with $5 \times 10^{5} / \mathrm{ml}$ tachyzoites of T. gondii. Autopsies were performed for light microscopic examination to study the histological changes.

Light microscopy: The liver, heart, kidney and brain of each studied mouse were fixed in $10 \%$ formalin, dehydrated and embedded in wax for light histo - pathologic examination. Hematoxylin and Eosin (H\&E) and Giemsa staining were used. Tachyzoites in the peritoneal fluid of all acutely infected mice were processed for microscopic study as previously described (Ventuini etal, 1996). In brief, they were fixed in $4 \%$ gluteraldehyde in $0.1 \mathrm{M}$ phosphate buffer, post-fixed in osmium tetroxide and treated with uranyl acetate prior to dehydration and embedded in Spurr's epoxy resin, before sectioning and staining for light microscopy.

T. gondii tissue cysts: $T$. gondii tissue cysts were obtained from brain tissue of naturally infected local breed mice. Brain tissue was grind, suspended in phosphate buffer saline (PBS), at $\mathrm{pH} \mathrm{7.2,} \mathrm{and} \mathrm{then} \mathrm{filtered} \mathrm{through} \mathrm{gauze.} \mathrm{One} \mathrm{ml} \mathrm{(containing}$ 100 tissue cysts) was injected in Swiss mice intraperitoneally as described by (Shotwell etal, 1996). Mice were daily inspected for any febrile sign.

Aflatoxins: AF were prepared through inoculation of rice with A. parasiticus NRRL 2999 and were incorporated into the diet to provide the described level of 0.5 and 1 
ppm_(obtained from Dr. Aqeel Mohammed Sharif in College of Veterinary medicine \ Mosul Universityl Iraq) as described by (West etal, 1973) and modified by (Nabney etal , 1965). Fermented rice was then autoclaved and grind. The aflatoxin content were measured by spectrophotometer analysis (Wiseman etal, 1967) (Ferguson etal, 1999)

Determination of Glutathione and Malondialdehyde: Serum glutathione was measured by a modified procedure utilizing Ellman`s reagent (D'Mello etal, 1997). while the level of malondialdehyde was carried out using the modified method of (Yazar etal, 2004).

Statistical analysis: The data were statistically analyzed using ANOVA as means \pm standard error of the mean, $\mathrm{P} \leq 0.05$ was considered significant.

\section{RESULTS AND DISCUSSION}

In the present study many histological changes were observed in mice intestine infected with $T$. gondii parasite fig (1). Numerous perivascular and leptomeningeal infiltrations of inflammatory cells were observed, occasional occurrence of necrosis of the brain parenchyma was also noticed, It was reported that necrotic foci followed by mononuclear inflammatory reactions are the most prominent lesions of toxoplasmosis in organs heavily infected with tachyzoites and this appears to be directly related to the rapid intracellular replication of the parasite (Jubb etal, 1993). The hazards of Aflatoxins may be either those of acute toxicity or those of long-term chronic toxicity and carcinogenicity, These toxicity had relationship with the route of administration, exposure period and dosage (Baptista etal, 2008). Mycotoxicoses were induced in mice by feeding AF $(0.5 \mathrm{ppm})$ to study the pathological changes, Degenerative and muscle fibers atrophy were observed in the myocardium of all toxin treated mice. However, in AF fed birds, haemorrhages were noticed in the epicardium and myocardium (Balachandran and Ramakrishnan, 1987). The liver is the target organ for AFB1. Ingestion of this mycotoxin, is known to be capable of inducing acute poisoning, aflatoxicosis, and is believed to be participated in the development of primary liver cancer (Neal, 1995). Moreover, under this pathological condition, the active process of cellular self-destruction, apoptosis, can occur (Meki etal, 2004). This may return to that AFs have induced oxidative damage and caused to generate free radicals which reacted with cellular component and led to pathological changes in liver and kidney functions (Clifford etal, 1967). This may referred to the action of cytochrome $\mathrm{P} 450$ which is secreted from liver cells, renal tubular cells and lung cells. This enzyme caused detoxification of toxin complex compound and this will lead to degeneration of organ cells and may cause cancer (Ankrah etal, 1993) coincide with (Choudhary and Verma, 2006) who carried out his experiment on AF by oral administration for 30 days and noticed significant increase in lipid peroxidation in the kidney, consequently, this explain increasing urea, uric acid and certain of blood serum level in AFs treated mice when compared with control animals. Histopathological changes observed in the livers of AF similar to (Colakoglu and Donmez, 2012). In experimental models of infection with T. gondii parasite, acute mortality can result either from a failure to control the parasite number or due to the excessive immunological response against the infection (Lawrence etal, 2003), It is very well known that hepatocytes are active metabolic cells and when such parasite invade the cell it can lead to disturbances in its metabolic activity which inturn leads to shape distortion, which could be due to edema and accumulation of fluid within the cells. Similar changes were also found by other 
workers and some relate the disturbances in the hepatocyte function and with $T$. gondii (Hussein and Brasel, 2001; Eissa etal, 1990). Microscopic examination also revealed intense infiltration of the liver with mixed inflammatory cells, these cells leave the blood and enter the tissues as a part of the immunological response of the mice to the infection with Toxoplasma Gondii parasite fig $(3,6,10)$, this change was also mentioned by other workers (Lawrence etal, 2003;Ferro etal, 1999). Also, this result agree with (Rana and Kassabbashi, 2007). So mechanisms of liver damage and the histological changes induced by $T$. gondii infection is either due to a direct effect of the parasite on the tissues leading to cell death and tissue damage or it could be related to indirect effect of infection due to the excessive immunological response to the parasite (Ferro etal, 1999). Reduction in protein content could also be due to increased hepatocellular necrosis. Thus, reduction in protein biosynthesis as well as increased necrosis could be responsible for a decrease in protein. Many other investigators reported a decrease in protein concentration in skeletal muscle (Raval and Verma 1992), heart (Neal, 1995)., liver and kidney (Meki etal, 2004; Clifford etal, 1967; Ankrah etal, 1993)of AF-fed animals. the pathological changes in different organs fig (2-5). the lesions were more marked and consisted of both the lesions seen in AF and T.gondii suggest the cumulative interaction of these toxins in inducing severe changes in organs fig (7-13). Placenta, brain and heart are the most commonly affected organs in Toxoplama induced abortion in sheep and goat (Dubey, 1988). Hence, T. gondii might affect the information processing within a wide variety of brain functional systems, provided that the parasite is able to alter brain function locally (Berenreiterova etal, 2011). At later stage of infection, it was comparatively easier to spot tachyzoites in the heart and diaphragm that reinforces tachyzoites proliferation in muscles, indicative of the subacute phase of $T$. gondii infection eventually leading to parasite encystations in muscles and brain (Frenkel, 1973).

Table (1) show that MDA level in liver tissue was significantly $(\mathrm{P}<0.05)$ increased in group (2), group (4), group (5) and group (6) as compared with group (1) normal healthy control and table (1)also show that GSH concentration in liver was significantly decreased in group (2) and group (4), group (5) and group (6) as compared with group (1) normal healthy control.GSH is an important constituent of intracellular protective mechanisms against a number of noxious stimuli including oxidative stress. It plays a role in preventing the transformation of hemoglobin into met hemoglobin due to oxidation. Moreover, it maintains the sulfhydryl (-SH) groups in proteins in a reduced state and protects these groups against oxidation (Akkus, 1995).

The MDA product can cause the cross-linkage of membrane elements by affecting the ion exchange from cell membranes, which gives way to aftermaths including a change in ion permeability and enzyme activity. In a previous study, it was reported that MDA increases in Toxoplasma seropositive patients (Yazar, 2004).A decrease in the GSH activity in Toxoplasma seropositive patients indicates a decline in the response to oxidative stresses. The high level of MDA suggest in the patients infected with toxoplasmosis could be the decreased activity of the defense system protecting the tissues from free radical damage (Gilbert, 1984). 
Mesopotamia J. of Agric.

Vol. (45) No. (4) 2017
ISSN: 2224 - 9796 (Online)

ISSN: 1815 - $316 \mathrm{X}$ (Print)

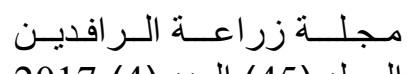

Table (1): Effect of Aflatoxin and Toxoplasma gondii on MDA and GSH level in liver tissue.

\begin{tabular}{|l|c|c|}
\hline \multicolumn{1}{|c|}{ Animal $\backslash$ group } & MDA & GSH \\
& $\mathrm{U} \mathrm{mol} / \mathrm{L}$ & $\mathrm{U} \mathrm{mol} / \mathrm{L}$ \\
\hline Control (group 1) & $17.24 \pm 0.10 \mathrm{~d}$ & $3.01 \pm 0.04 \mathrm{a}$ \\
\hline Toxoplasma (group 2) & $24.05 \pm 0.38 \mathrm{~b}$ & $1.80 \pm 0.11 \mathrm{c}$ \\
\hline Aflatoxin (0.5 ppm) (group 3) & $17.98 \pm 0.91 \mathrm{~d}$ & $3.09 \pm 0.12 \mathrm{a}$ \\
\hline Aflatoxin (1 ppm) (group 4) & $19.10 \pm 0.01 \mathrm{c}$ & $2.12 \pm 0.20 \mathrm{~b}$ \\
\hline Aflatoxin 0.5 ppm and injected with T. gondii tissue cysts (group 5) & $24.10 \pm 0.42 \mathrm{~b}$ & $1.89 \pm 0.62 \mathrm{c}$ \\
\hline Aflatoxin 1 ppm and injected with T. gondii tissue cysts (group 6) & $27.08 \pm 0.54 \mathrm{a}$ & $1.02 \pm 0.12 \mathrm{~d}$ \\
\hline
\end{tabular}

Different letters in column differ significantly at level of $\mathrm{P}<0.05$, Mean \pm SE for 10 mice.

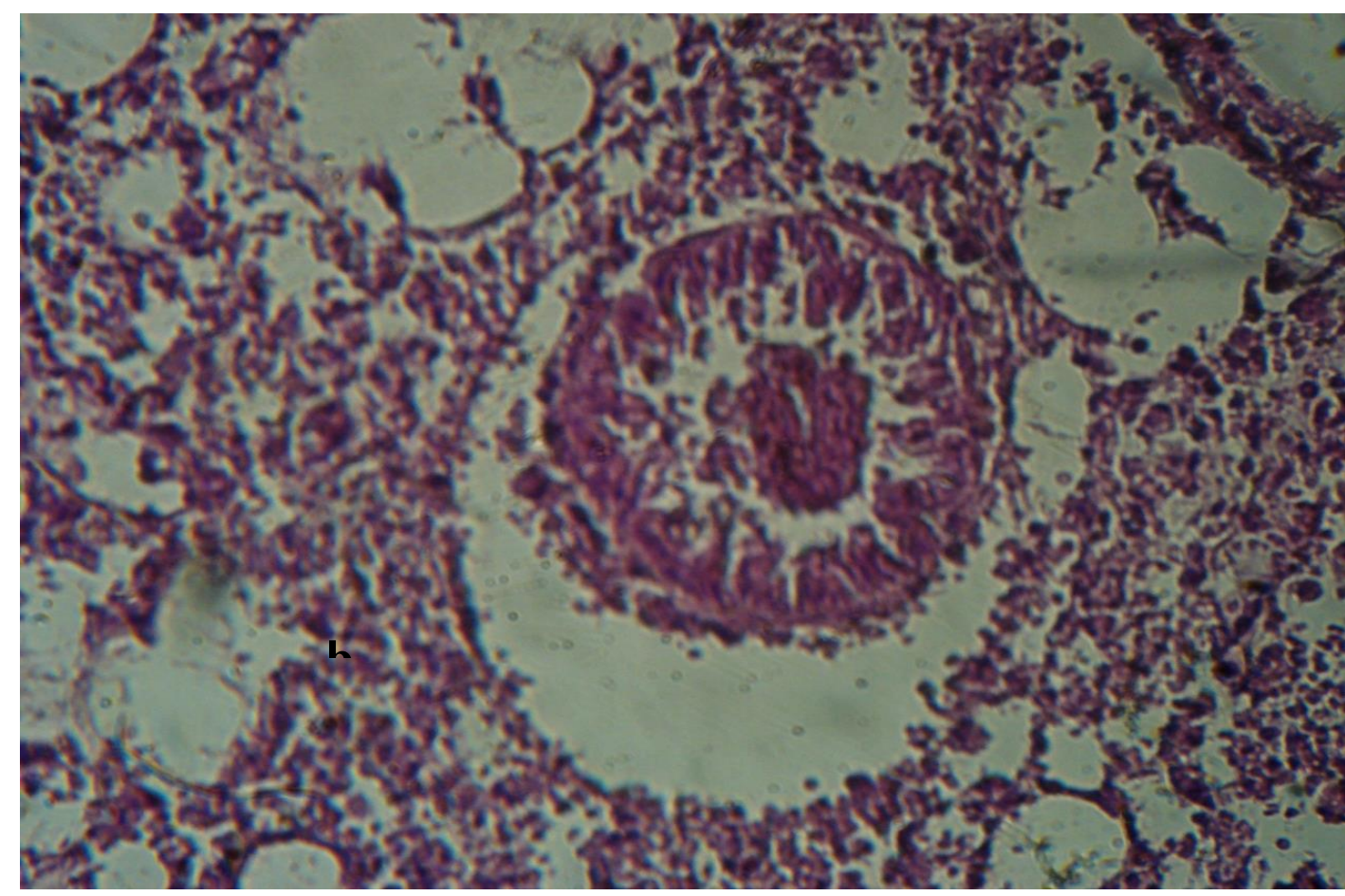

Fig. (1): Photomicrograph section of mice intestine, injected with toxoplasma tissue cysts, showed mucus cell proliferation (a), lymphocyte infiltration (b) tissue cyst (c). H\&E, $165 \mathrm{X}$. 


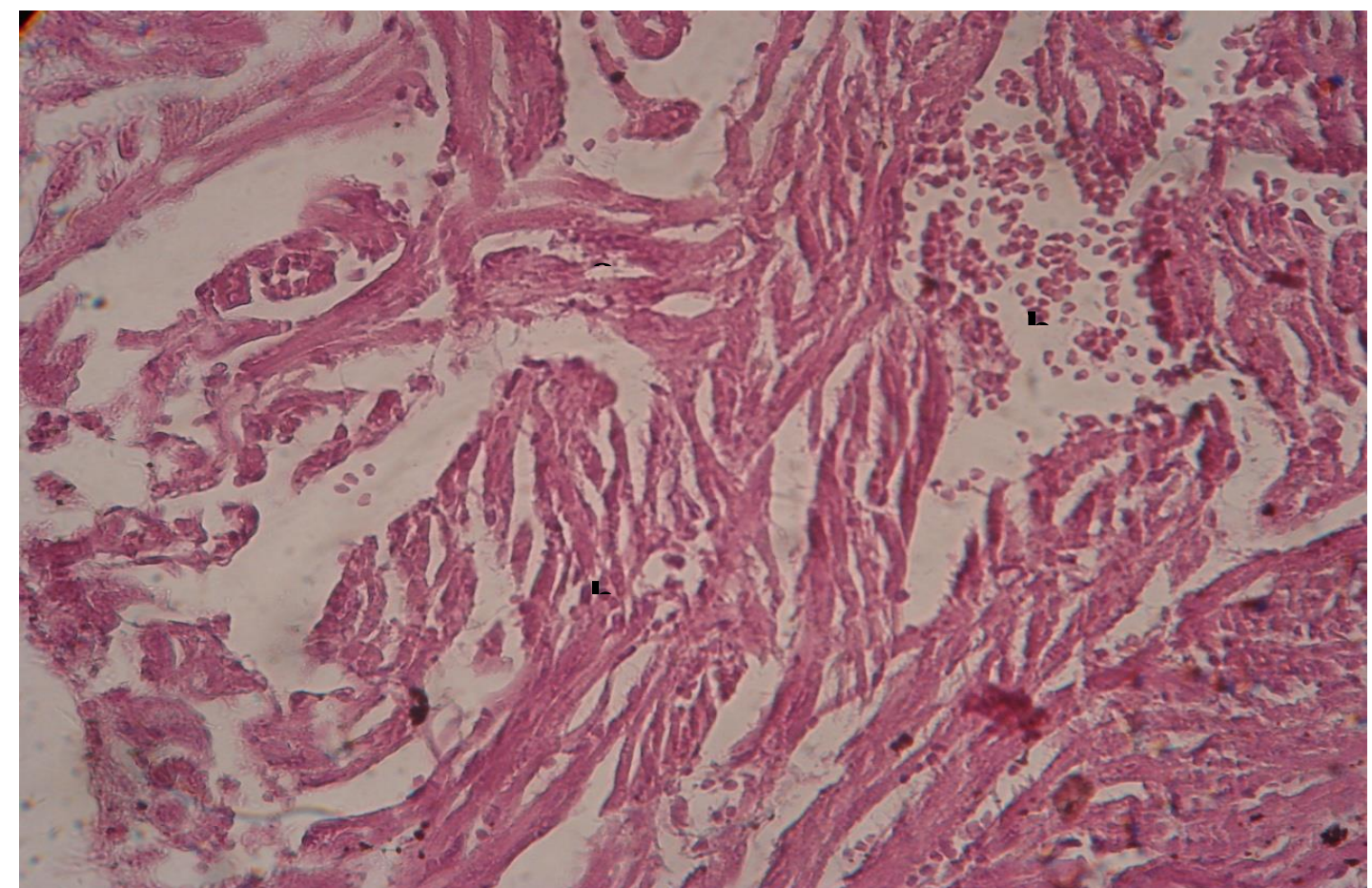

Fig. (2): Histological section of mice heart, fed diet contaminated with $0.5 \mathrm{ppm}$ AF, showed muscle fibers atrophy (a) and tissue cyst (b). H\&E, $145 \mathrm{X}$.

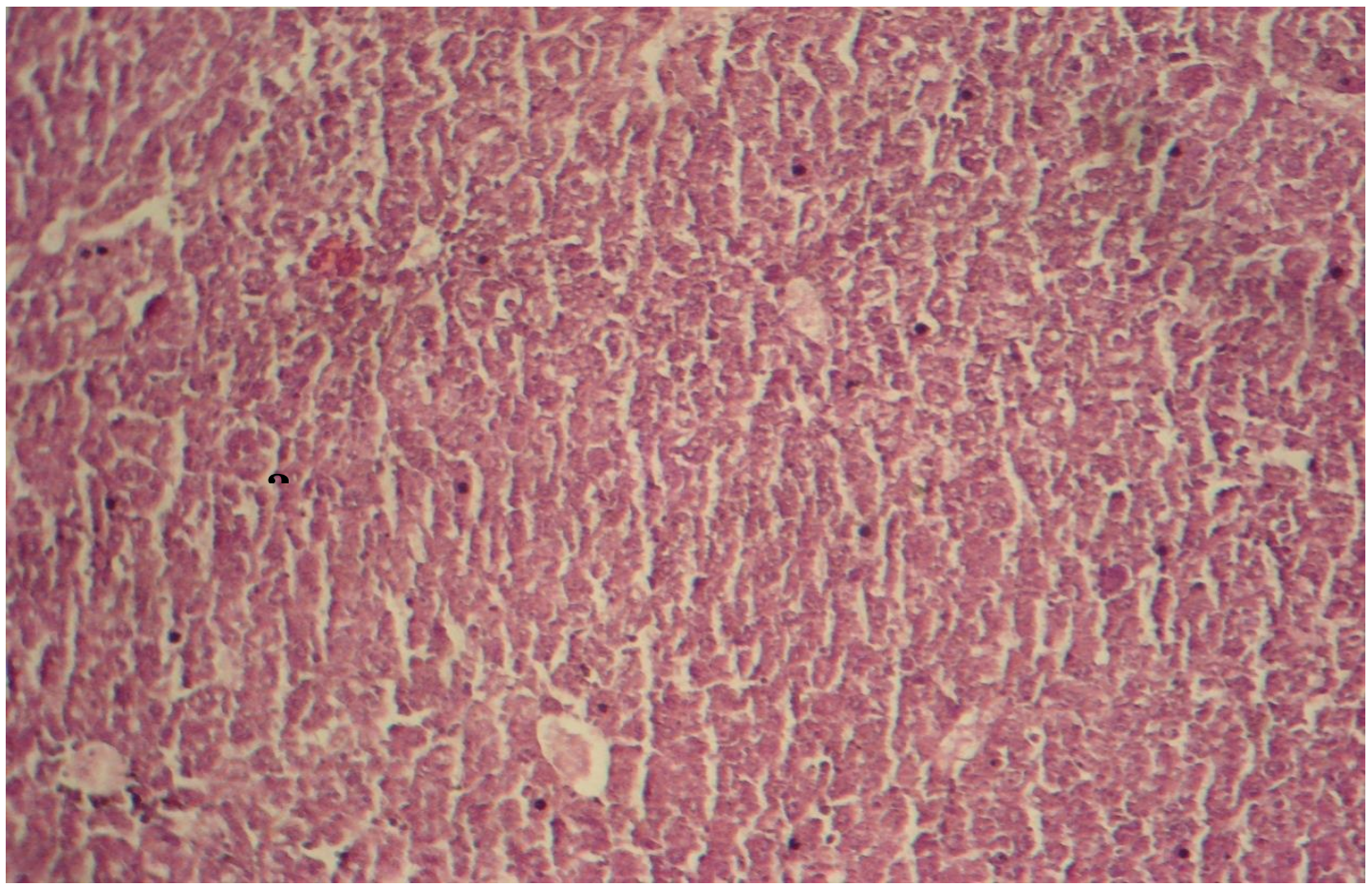

Fig. (3): Histological section of mice liver, fed diet contaminated with $1 \mathrm{ppm} \mathrm{AF}$, showed loss of lobular architecture with moderate paranchymal cell necrosis (a).H\&E, $115 \mathrm{X}$. 


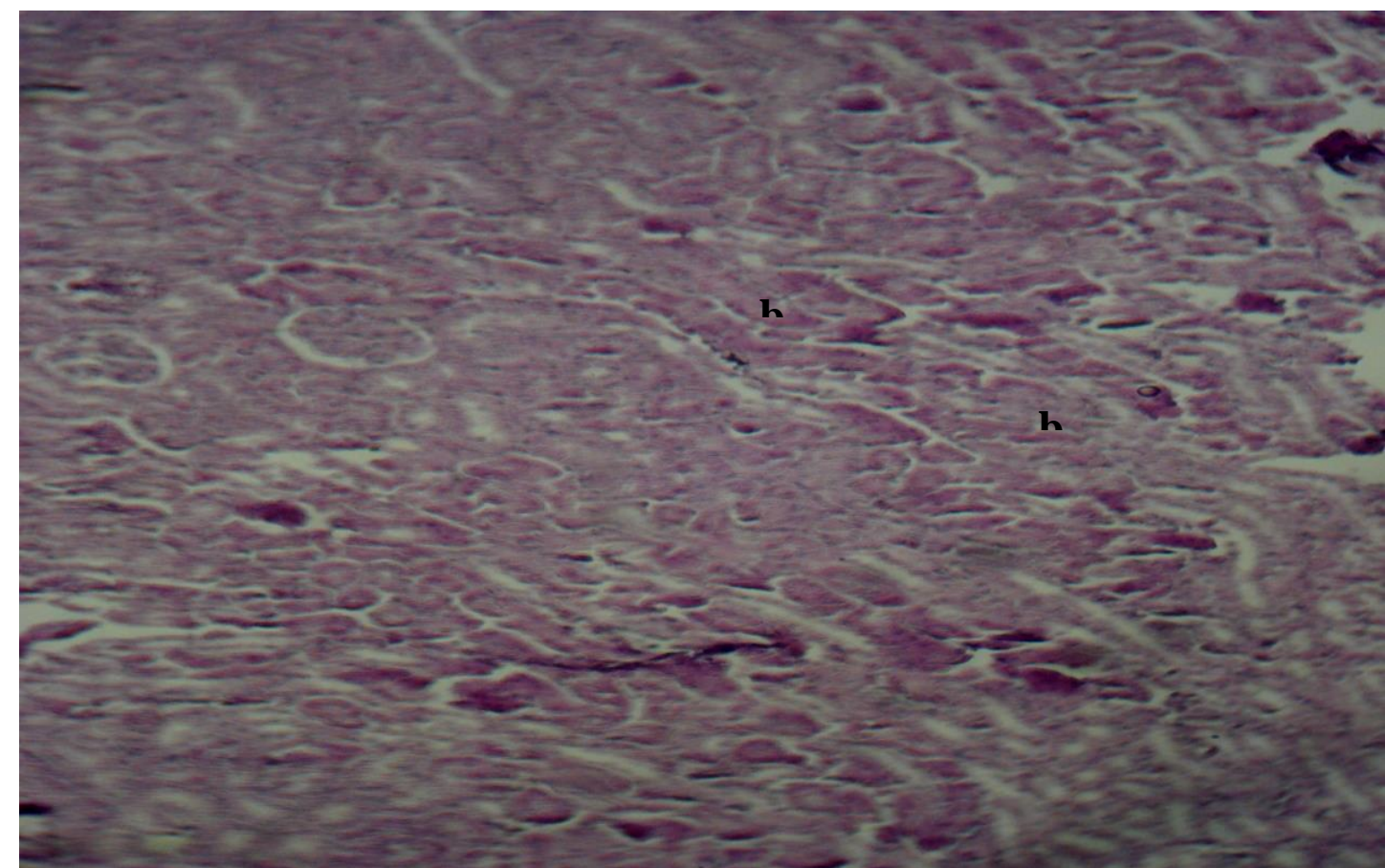

Fig. (4): Histological section of mice kidney, fed diet contaminated with $1 \mathrm{ppm}$ AF, showed glomerular fibrosis (a) and sclerosis (b). H\&E, $145 \mathrm{X}$.

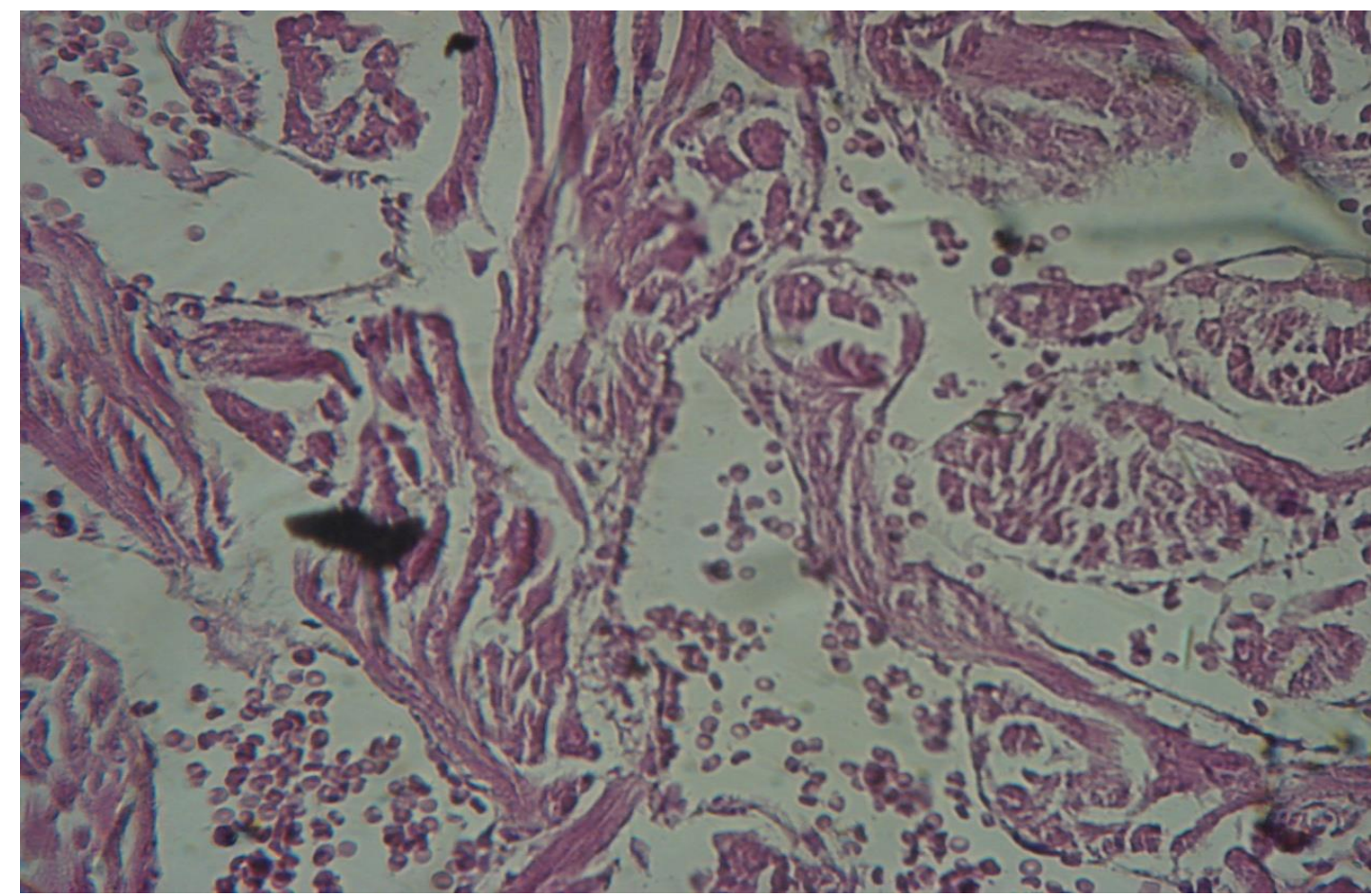

Fig. (5): Histological section of mice heart, fed diet contaminated with $1 \mathrm{ppm}$ AF, showed atrophy of muscle fibers and shrinkage of fibers (a) H\&E, $145 \mathrm{X}$. 


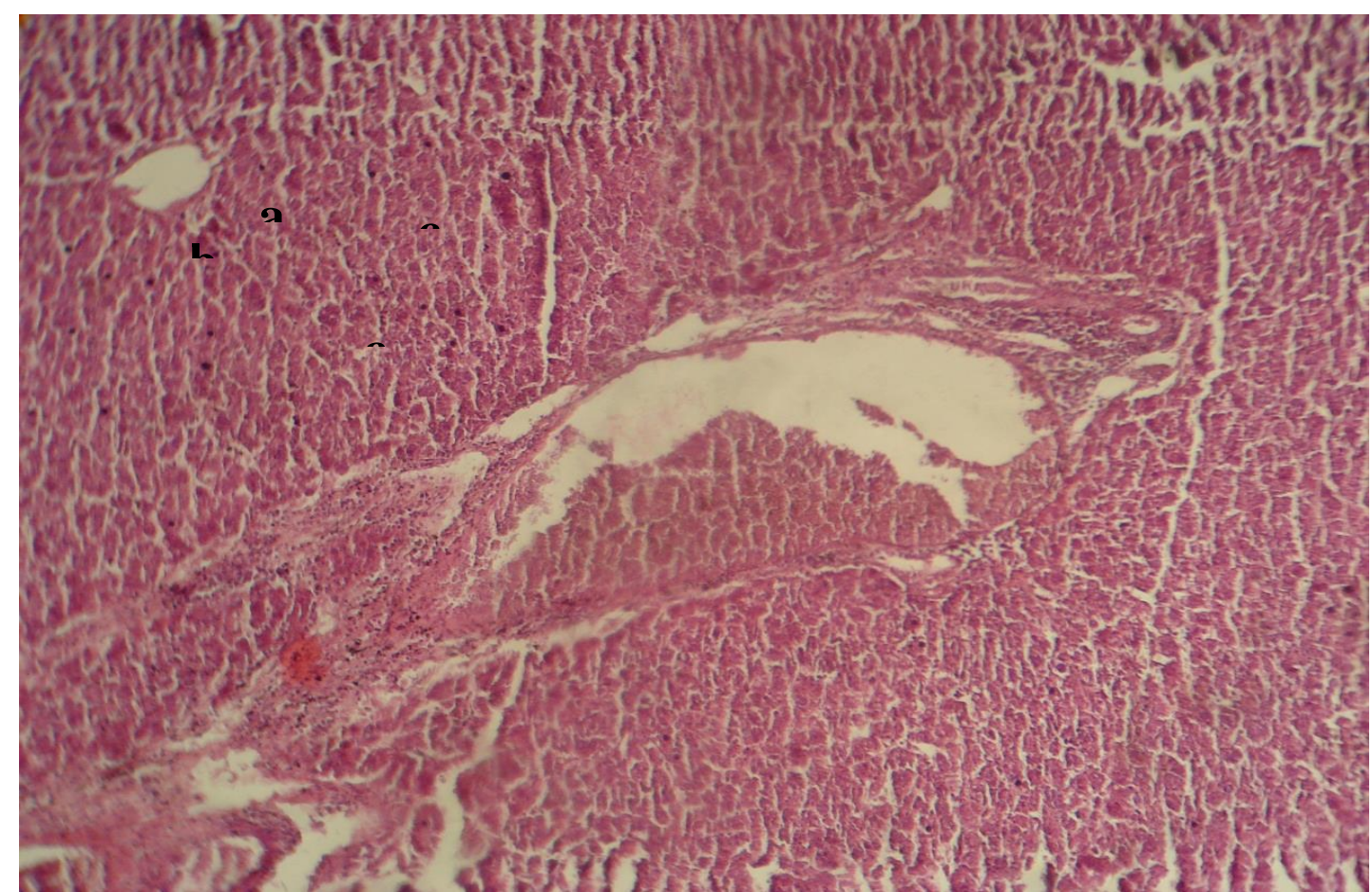

Fig. (6): Histological section of mice liver, fed diet contaminated with $0.5 \mathrm{ppm}$ AF and injected with toxoplasma tissue cysts, showed loss of lobular architecture with paranchyma cell necrosis (a), lymphocytic hyperplasia (b) and tissue cyst (c). H\&E, $115 \mathrm{X}$.

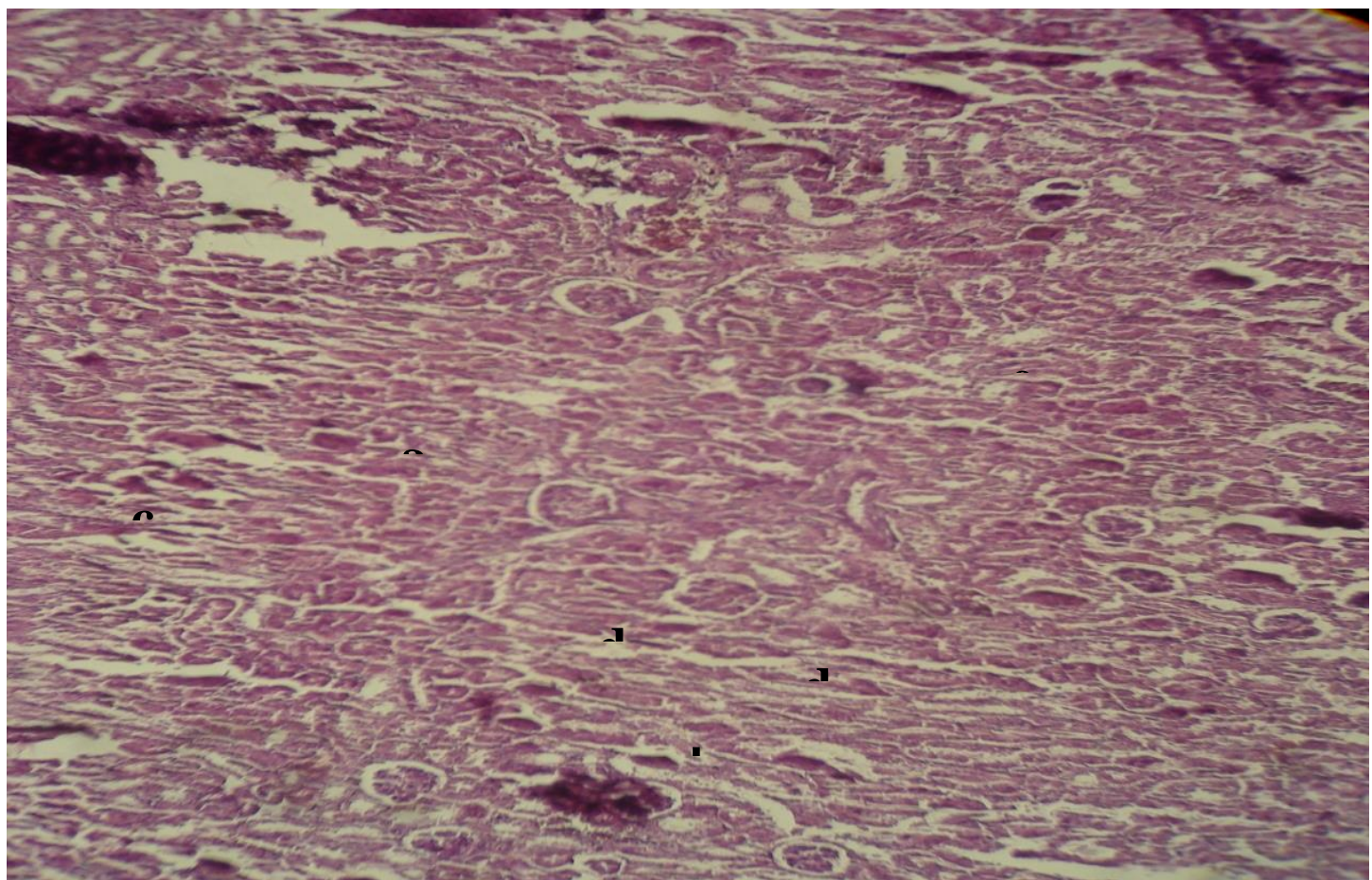

Fig. (7): Histological section of mice kidney, fed diet contaminated with $0.5 \mathrm{ppm}$ AF and injected with toxoplasma tissue cysts, showed fibrosis (a), sclerosis (b), segmental necrosis (c), glomerular capillary collapse (d) and tissue cyst (e). $\mathrm{H} \& \mathrm{E}, 115 \mathrm{X}$. 


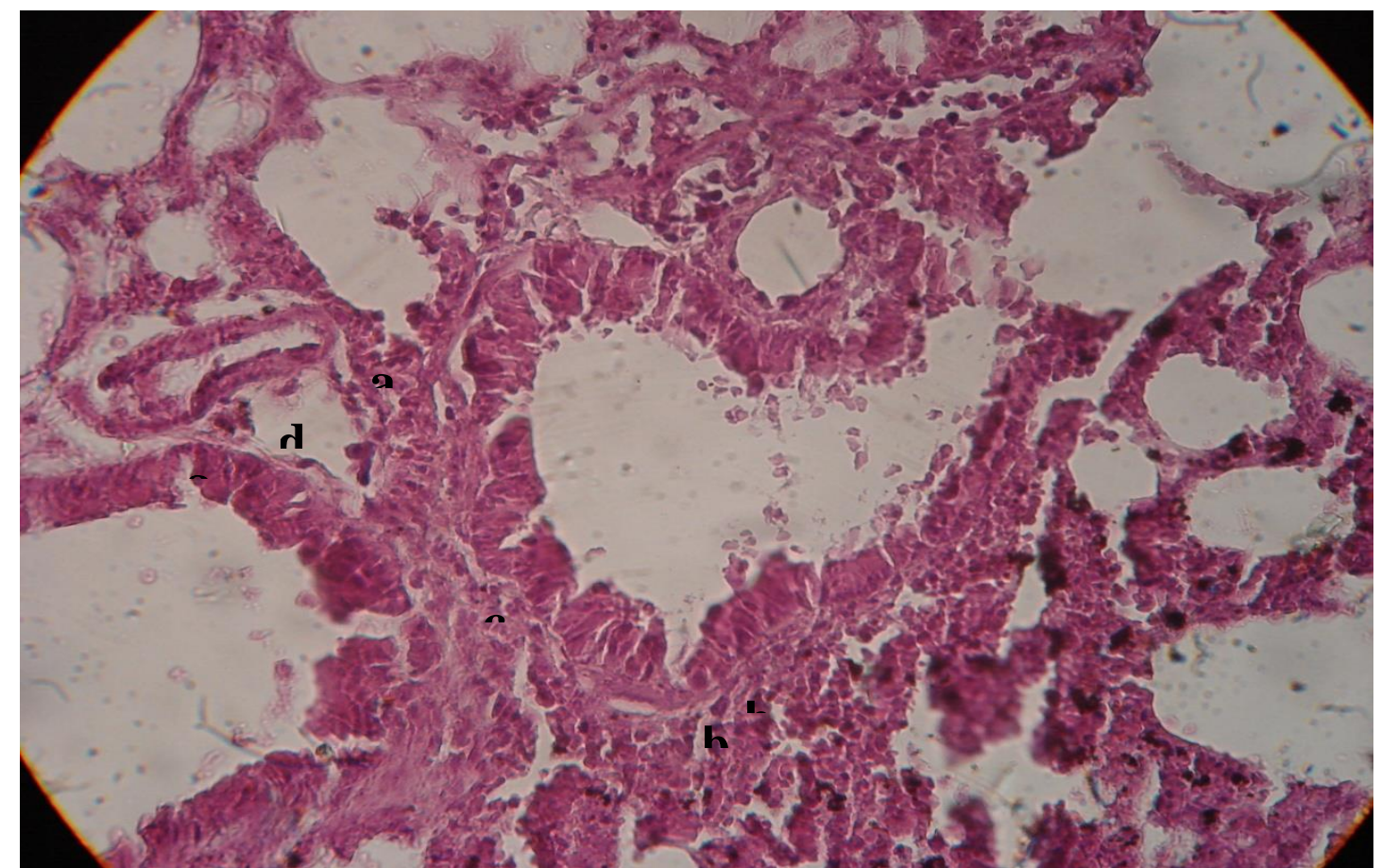

Fig. (8): Histological section of mice intestine, fed diet contaminated with $0.5 \mathrm{ppm}$ AF and injected with toxoplasma tissue cycts, showed glandular proliferation (a), with lymphocytic infiltration (b) and epithelial proliferation (c) tissue cyst(d). H\&E, 165 X.

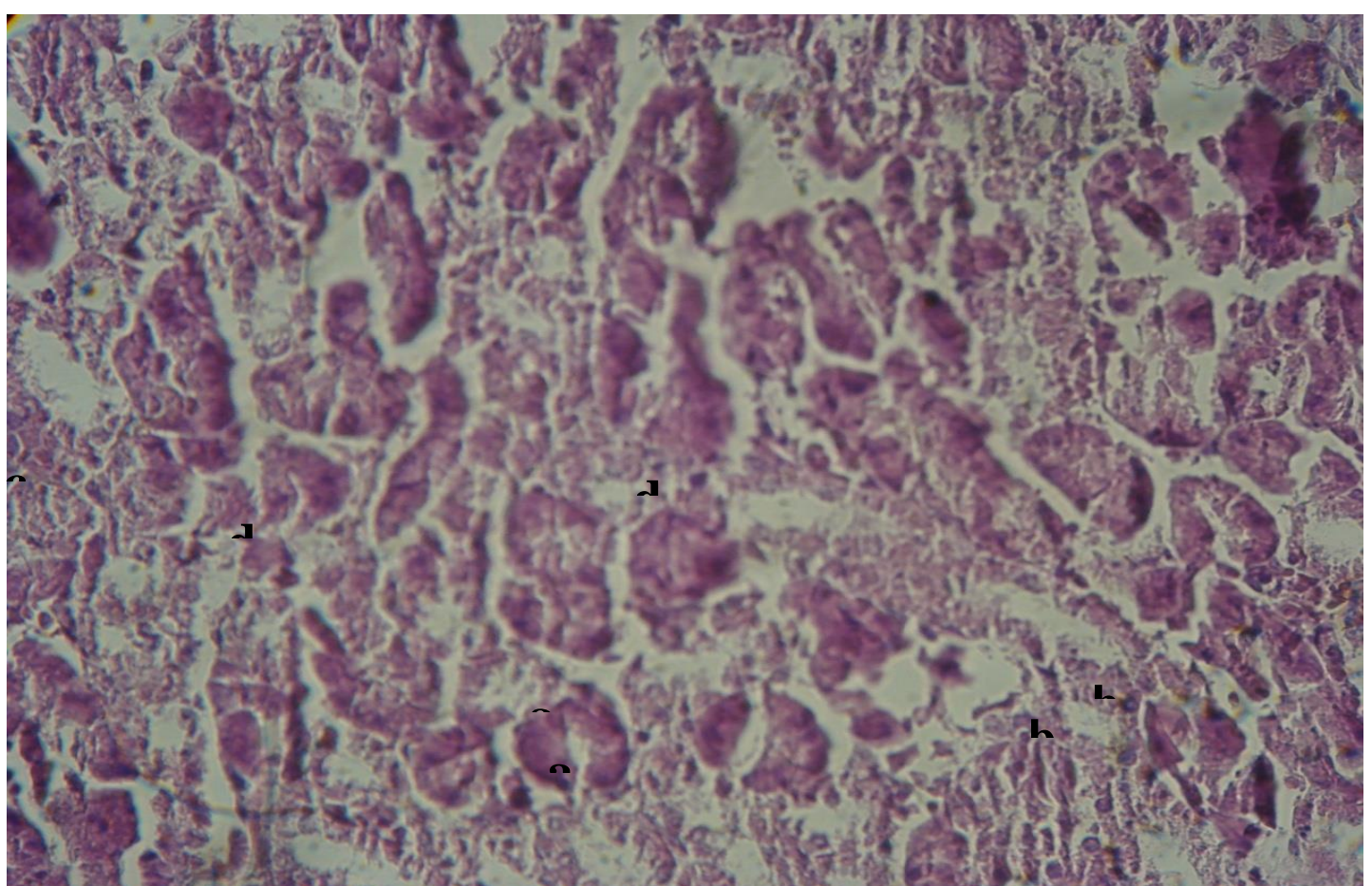

Fig. (9): Histological section of mice brain, fed diet contaminated with 1ppm AF and injected with toxoplasma tissue cysts, showed focal moderate necrosis (a), foci of gliosis (b) and lymphocytic infiltration (c) tissue cyst (c). H\&E, 165 $\mathrm{X}$ 
Mesopotamia J. of Agric.

Vol. (45) No. (4) 2017
ISSN: 2224 - 9796 (Online)

ISSN: 1815 - $316 \mathrm{X}$ (Print)

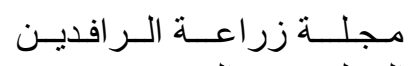

المجلد (45) العدد (4) 2017

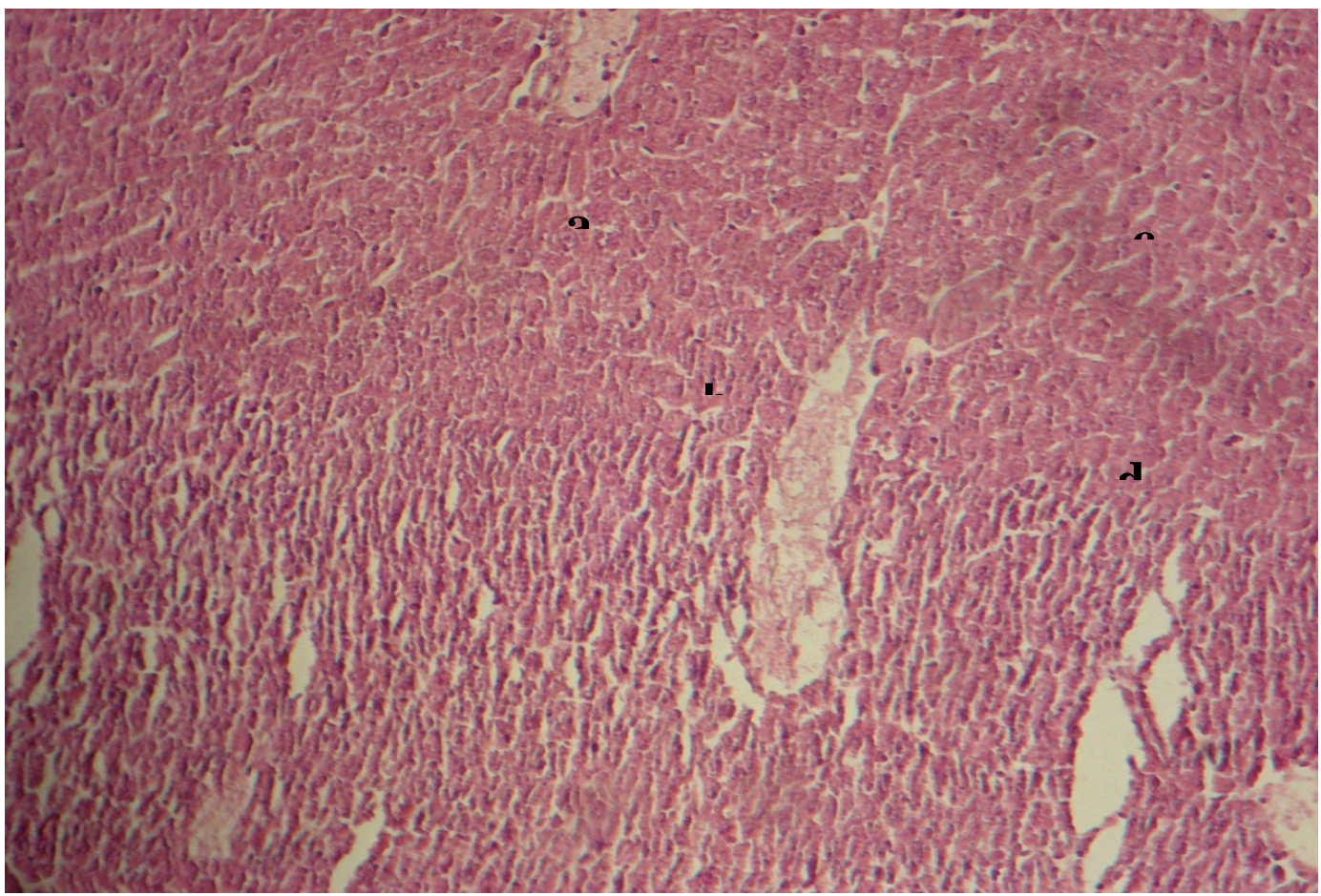

Fig. (10): Histological section of mice liver, fed diet contaminated with 1ppm AF and injected with toxoplasma tissue cysts, showed paranchymal cell proliferation (a), sever necrosis (b), mild lymphocytic infiltration (c) tissue cyst (d). H\&E, $115 \mathrm{X}$.

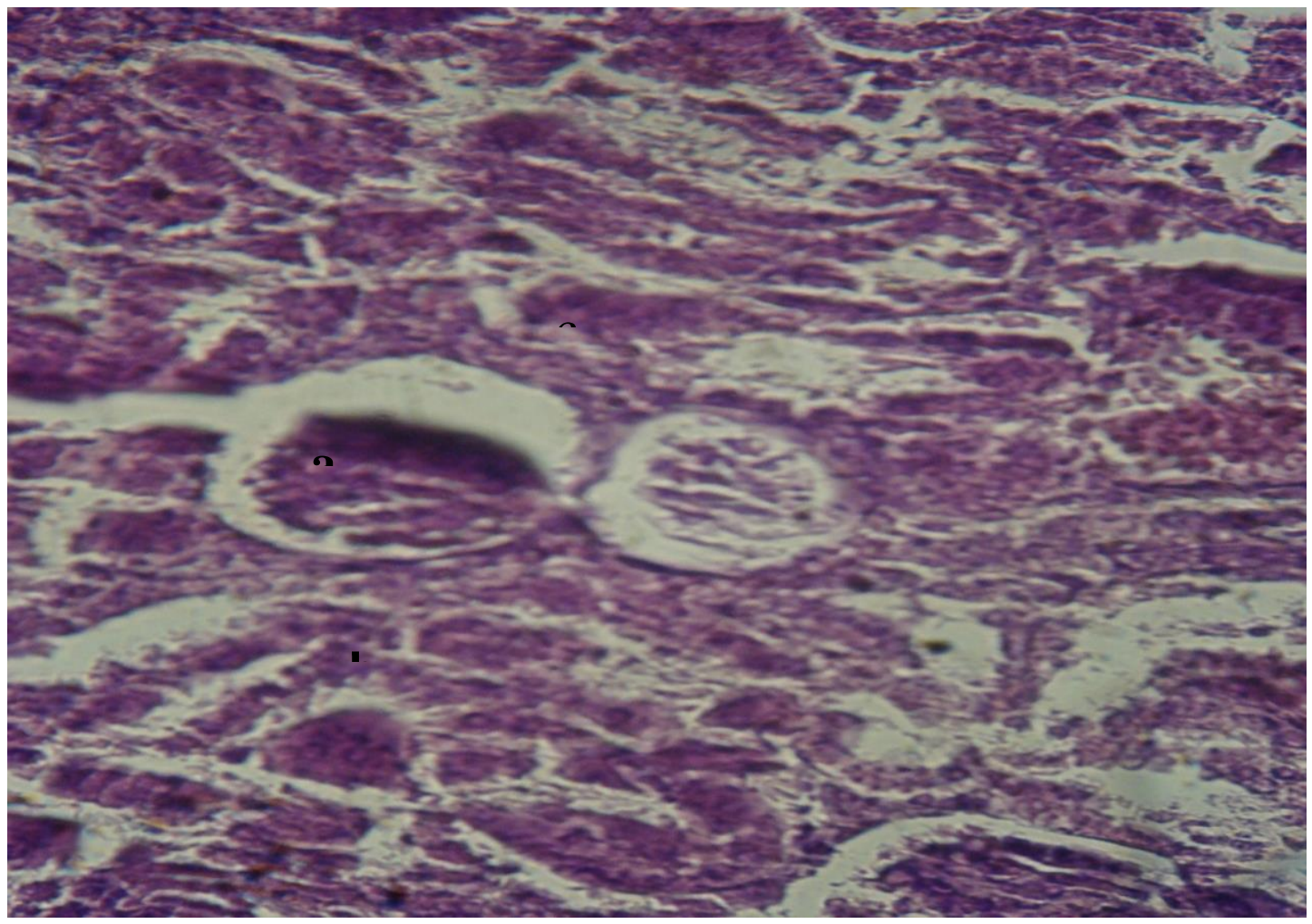

Fig. (11): Histological section of mice kidney, fed diet contaminated with 1ppm AF and injected with toxoplasma tissue cysts, showed glomerular sclerosis (a), focal necrosis (b), endothelial proliferation (c). H\&E, $145 \mathrm{X}$. 


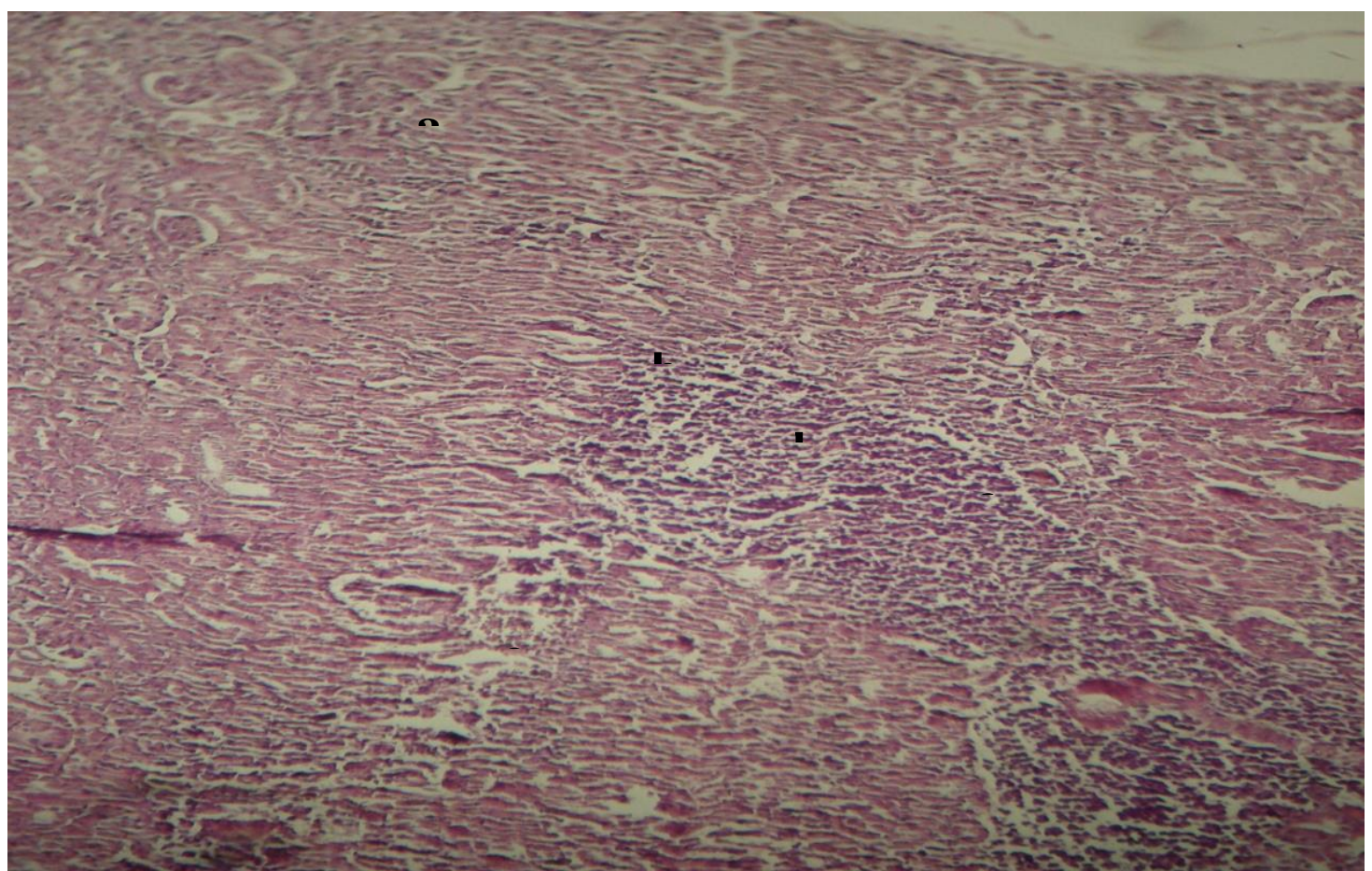

Fig. (12): Histological section of mice intestine, fed diet contaminated with $1 \mathrm{ppm} A F$ and injected with toxoplasma tissue cysts, showed mucus secreting cell proliferation and glandular proliferation (a), with sever lymphocytic infiltration (b) and tissue cyst (c). H\&E, $115 \mathrm{X}$

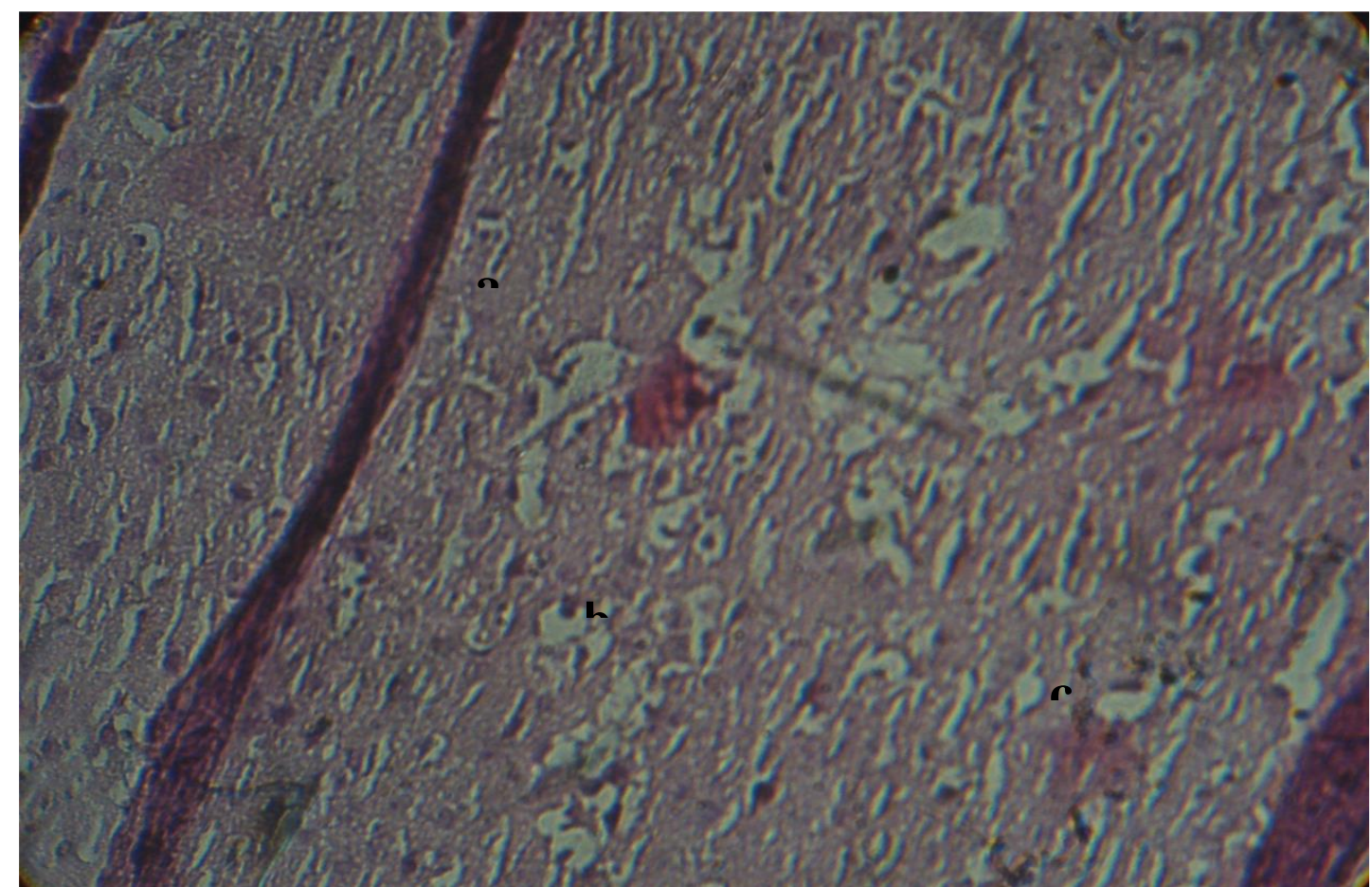

Fig. (13): Histological section of mice brain, fed diet contaminated with $0.5 \mathrm{ppm}$ AF and injected with toxoplasma tissue cysts, showed focal necrosis (a), foci of gliosis (b), mild lymphoid inflammation (c). H\&E, 115 X. 
دراسة نسجية كيموحيوية لتأثير الاصابة التجريبية بالمقوسات القتديةوالتسمم بذيفانات الافلاتوكسين في الفئران

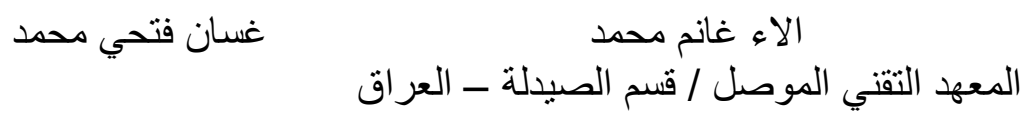

إحسان كوركيس زكريا

E-mail: gorgees.ehsan@yahoo.com

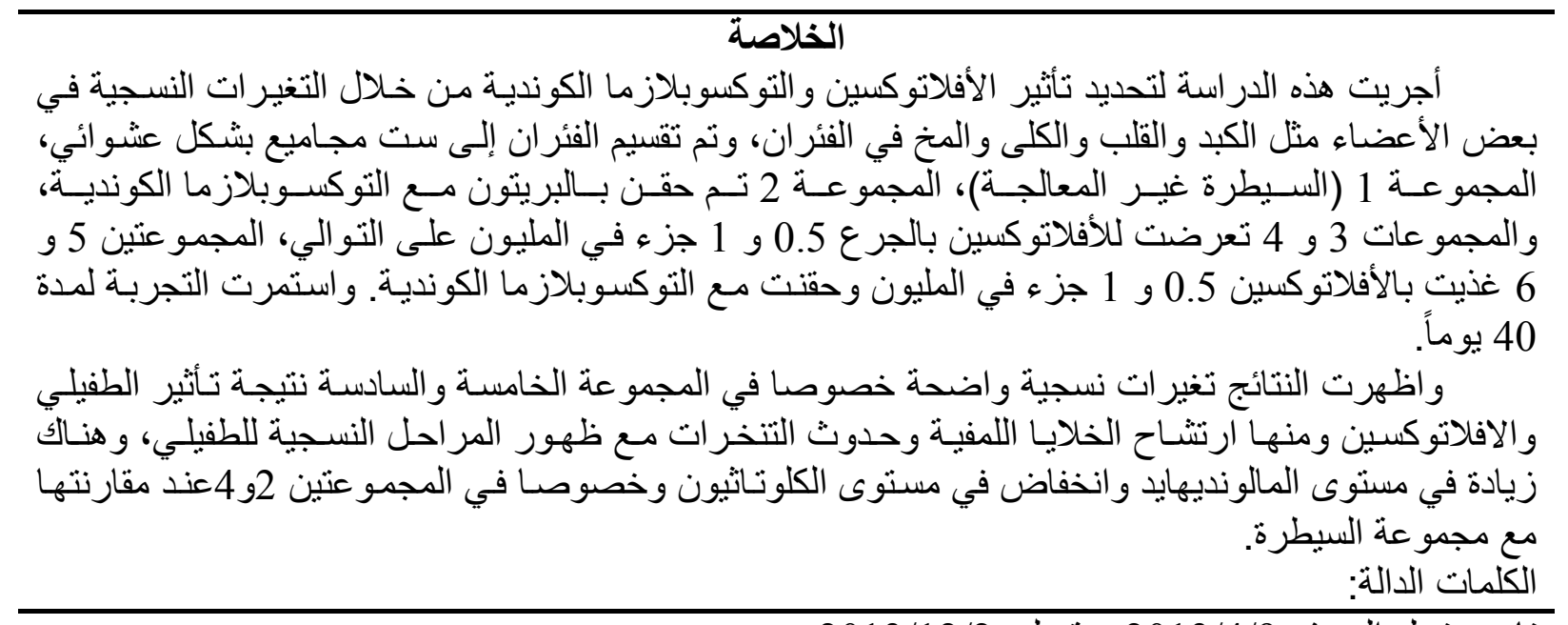

\section{REFERENCES}

Akkus, I. (1995). Effects Of Free Radicals And Pathophysiological. Konya, Turkey. Mimoza Publisher: 32ISBN 975-543-038-5. p 1-76.

Ankrah, N. A.; P. G. Addo; F. A. Abraham and M. M. Addae (1993). Comparative effects of aflatoxins $\mathrm{G} 1$ and B1 at levels within human exposure limits on mouse liver and kidney. West Africa Journal Medicine 12 (2):105-109.

Balachandran, C.and, R. Ramakrishnan (1987). An experimental study on the pathology of aflatoxicosis in broiler chicken. Indian Veterinary Journal 64, 911 914.

Baptista , A. S.; A. L. Abdalla and C. L. Aguiar (2008). Utilization of diets amended with yeast and amino acids for the control of aflatoxicosis. World Journal of Microbiology and Biotechnology 24 (11): 2547-2554.

Berdoy, M.; J.P. Webster and D.W. Macdonald (2000). Fatal attraction in rats infected with Toxoplasma gondii. Proceeding Biological Science 267 (1452): 1591-4.

Berenreiterova, M.; J. Flegr and A. Kube (2011). The distribution of toxoplasma gondii cysts in the brain of a mouse with latent toxoplasmosis: Implications for the Behavioral Manipulation Hypothesis. Public library of science 6 (12):1-14.

Catterall, F.; E. Copeland and M.N. Clifford (2003). Ioannides C.: effects of black tea theafulvins on aflatoxin B (1) mutagenesis in the Ames test. Mutangenesis 18 (2): 145-50.

Choudhary, P. and R. J. Verma (2006). Black tea ameliorates Aflatoxin-induced lipid peroxidation in the kidney of mice. Acta Poloniae Pharmaceutica-Drug Research 63 (4):307-310.

Clifford, J. I.; K. R. Rees and E. M. Stevens (1967). The effect of the aflatoxins B1, G1 and G2 on protein and nucleic acid synthesis in rat liver. Biochemistry Journal $103(1): 258-261$. 
Colakoglu, F. and H. H. Donmez (2012).Effects of aflatoxin on liver and protective effectiveness of esterified glucomannan in merino rams. Scientific World Journal. Vol. 2012, Article ID 462925, 5 pages

D'Mello J.P. ; J.K. Parter; A.M.C. Macdonald and C.M. Placinta (1997). Fusarium Mycotoxin in Plant and Fungal Toxicant, Handbook Edited by J.P. D'Mello, Published By CRC Press, Boca Raton, New York, pp: 287-297.

Dubey, J.P. (1988). Lesions in transplacentally induced toxoplasmosis in goats. American Journal Veterinary Reserch 49: 905-909.

Eissa, M.H; S.N. Antonious; M.M. Salama; A.A. Fikry and T.A. Morsy (1990). Histopathological studies of acute, chronic and congenital infections of toxoplasmosis in mice. Journal Egypt Society Parasitology 20 (2): 805-816

Ferguson, D.J.P.; M.F. Cesbron-Delauw; J.F. Dubremertz; L.D. Sibley; K.A. Joiner and S.E. Wright (1999). The expression and distribution of dense granule proteins in the enteric (coccidian) forms of Toxoplasma gondii in the small intestine of the cat. Experimental Parasitology 91: 203-11.

Ferro, E.A.V.; E.S. Bevilaqua ; D.A.O. Silva and J.R. Mineo (1999). Trophoblast cells as a host cells to Toxoplasma Gondii. Parasitology Reserch 85 (8-9): 647-654

Flegr, J.; J. Klose; M. Novotná ; M. Berenreitterová and J. Havlíček (2009). Increased incidence of traffic accidents in Toxoplasma-infected military drivers and protective effect $\mathrm{RhD}$ molecule revealed by a large-scale prospective cohort study. Bib Medical Central Infectious Diseases 9: 72. doi:10.1186/1471-2334-9-72.

Frenkel, J.K. (1973). Toxoplasmosis: Parasite Life Cycle, Pathology and Immunology. In: The Coccidia: Eimeria, Isopora, Toxoplasma and Related Genera. (Hammond D \& Long P (eds.). Baltimore: University Park Press p. 346-400.

Gilbert, H.S.; D.D. Stump and F.F. Roth (1984). A method to correct for errors caused by generation of interfering compound during erythrocyte lipid peroxidation. Analytical Biochemistry 137:282-28.

Godin, D.; S. Wohaieb and A. Goumeniouk (1988). Antioxidant enzyme alterations in experimental and clinicaldiabetes. Molecular Cell Biochemistry 84, 223-231.

Hiba, S.A. (2007). Estimation of Aaflatoxin Levels For Some Raw Milk Types and Cheeses In Mosul City (MSc. Thesis), Mosul: Mosul University.

Hussein, H.S., Brasel, J.M., (2001). Toxicity, metabolism and impact of mycotoxins on human and animals. Toxicology 167, 101-134.

Jubb, K.V.; P.C. Kennedy and N. Palmer (1993). Pathology of Domestic Animals. 3 ed. Academic Press, Inc., New York, London.

Koltas, I.S.; G. Yucebilgic; C.K. Parsak and G. Sakman (2006). Serum malondialdehyde level in patients with cystic echinococcosis. Journal Saudi Medicine 27: 1703-1705.

Lawrence, L.J.; N.B. Kiera; M.S. Frank; C. Wangxue and T.S. Stephen (2003). Fibrin mediated protection against infection-stimulated immunopathlogy. Journal Experimental Medicine 197 (6):801-806.

Luyendyk, J.P.; B.L. Copple; C.C. Barton; Ganey P.E. and R.A. Roth (2003).Augmentation of aflatoxin B1, hepatoxicity by endotoxin involvement of endothelium and the coagulation system. Toxicology Science 72: 272-81.

Meerburg, B. and A. Kijlstra (2009). Changing climate-changing pathogens: Toxoplasma gondii in North-Western Europe. Parasitology Research 105 (1): 1724. 
Meki, A.R.; D. Esmail and H.M. Hassanein (2004). Caspase-3 and heat shock protein70 in rat liver treated with aflatoxin B1: effect of melatonin. Toxicon Journal 43 (1):93-100.

Nabney, J.and B.F. Nesbitt ( 1965). A spectrophotometric method of deterring aflatoxin. Journal Analyst 90:155-160.

Neal, G.E. (1995). Genetic implications in the metabolism and toxicity of mycotoxins. Toxicology Letters 82:861-867.

Nishikawa, Y. O. Kawasa; O. Vielemeyer; H. Suzuki and H. Nagasawa (2007). Toxoplasma gondii infection induces apoptosis in noninfected macrophages: role of nitric oxide and other soluble factors. Parasite Immunology 29: 375-385.

Rana, M. R. Kassabbashi, (2007). Histological Changes of Mice Liver Infected With Toxoplasmosis. Tikrit Medical Journal 13 (2):103-108.

Raval, P.J. and R.J. Verma (1992). Alterations in biochemical composition of skeletal muscle during aflatoxicosis in rabbits. Bulletin Environmental Toxicology 49 (6) $855-860$.

Ryan, K.J. and C.G. Ray (2004). Medical Microbiology (4 ${ }^{\text {th }}$ ed.). McGraw Hill. pp.723-730.

Shareef, A.M. (2004). The effect of two commercial bentonites in improving broiler performance during aflatoxicosis. Iraqi Journal Veterinary Science:18:101-109.

Sher, A.; R.T. Gazzinelli ;I.P. Oswald; M. Clerici; M. Kulberg; E.J. Pearce, J.A. Berzofsky; T.R. Mosmann; S.L. James; H.C. Morse and G.M. Shearer ( 1992). Role of T-cell derived cytokines in the down regulation of immune responses in parasitic and retroviral infection. Immunological Review 127:183-204.

Shotwell, D.L.; C.W. Hessiltine; R.D. Stubblefield and W.G. Sornson ( 1996). Production of aflatoxin on rice. Journal Applied Microbiology 14:425-428.

Sukthana, Y.; P. Waree; E. Pongponratn; U. Chaisri and M. Riganti (2003). Pathologic study of acute toxoplasmosis in experimental animals. Southeast Asian Journal Tropical Medicine Public Health 34 (11): 16-21.

Torda, A. (2001). Toxoplasmosis: are cats really the source. Australian Family Physician 30 (8): 743-7.

Uchiyama, M.and M. Mihara (1978). Determination of malondialdehyde precursor in tissues by thiobarbituric acid test. Analytical Biochemistry 34: 271-8.

Venturini, M.C.; M.A. Quiroga and M.N. Risso (1996). Mycotoxin T-2 and aflatoxin B1 as immunosuppressors in mice chronically infected with Toxoplasma gondii. Journal Comp Pathology 115:229-237.

Vismara, C.and F. Caloni (2007). In: birth defects research part B: developmental and reproductive toxicology special issue: Female Reproductive Physiology and Toxicology Review Series. 80, 183.

Von Finckenstein, W.; S. Wedel; M. Angerer and M. Wienbeck (1992). Chronic subdural haematoma with Toxoplasma gondii in a patient with AIDS. International Conference on AIDS. 8:145.

West, S.; R. D. Wyatt and P.B. Hamilton (1973). Increases yield of aflatoxin by incremental increases of temperature. Journal Applied Microbiology 25:10181019.

Wiseman, H.G.; W.C. Jacobson and W.C. Hermeyer ( 1967). Note on removal of pigments from chloroform extracts of aflatoxin cultures with copper carbonate. Journal Association Official Agricultural Chemists 50:982-983. 
Yang, C.F.; J. Liu; S. Wasser; H.M. Shen and C.E.L. Tan (2000). Aflatoxine - induced biochemical changes in liver of mice and its mitigation by black tea extract. Carcinogenesis 21, 2237.

Yazar, S.; E. Kilic; R. Saraymen and H. Ozbilge ( 2004). Serum malondialdehyde levels in patients infected with plasmodium. West Indian Medical 53: 147-149.

Yazar, S.; E. Kilic; R. Saraymen and I. Sahin (2003). Serum malondialdehyde levels in Toxoplasma seropositive patients. Annals Saudi Medicine 23: 413-415. 